\title{
STUDIES ON THE MECHANISM OF ANTIFUNGAL ACTION OF ACULEACIN A
}

\author{
Hideyo Yamaguchi, Tamio Hiratani, Kazuo Iwata* \\ and Yoshimasa YamaMOTO* \\ Department of Microbiology, Faculty of Medicine, University of Tokyo, \\ 7-3-1 Hongo, Bunkyo-ku, Tokyo, 113 Japan \\ *Department of Microbiology, Meiji College of Pharmacy, \\ 1-35-23 Nozawa, Setagaya-ku, Tokyo, 154 Japan
}

(Received for publication November 12, 1981)

\begin{abstract}
Aculeacin A was lethal for proliferating cultures of C. albicans. However, there was a paradoxical relationship between the drug concentration and the fungicidal activity; the lethal effect was the greatest at levels of 0.08 to $1.25 \mu \mathrm{g} / \mathrm{ml}$ and increases in the drug concentration above this range reduced its lethal effect. A similar anomalous dose-response patterns were also observed for the inhibitory effect of the drug on several cellular and subcellular biochemical activities. Association of this lethal effect of the drug was the formation of visible cell aggregates and the development of extremely huge forms in treated cultures. Aculeacin A induced osmotically fragile cells and viability of treated cultures was markedly reversed under high osmolarity. Tracer experiments and chemical analysis revealed that synthesis of alkaliinsoluble glucan was inhibited by the drug to a greater extent than synthesis of mannan and any other species of macromolecules, with resultant formation of alkali-insoluble glucan-deficient cells. Aculeacin A inhibited synthesis of $\beta$-glucan from UDP-glucose catalyzed by cell-free extracts from C. albicans and S. cerevisiae. These data are consistent with the view that one of the principal target of aculeacin $\mathrm{A}$ action is on the $\beta$-1,3-glucan synthetase reaction.
\end{abstract}

Aculeacin A is the main component of a new family of antibiotic complex produced by Aspergillus aculeatus and strongly inhibits the growth of Candida yeasts in vitro. ${ }^{1,2)}$ The chemical structure of aculeacin A containing a cyclopeptide moiety and a long-chain fatty acid, palmitic acid, is closely related to that of echinocandin B which possesses linoleic acid instead. ${ }^{1,3,4)}$ These two antibiotics share the common antimicrobial spectrum; they are active against some species of yeasts but have little activity against other yeasts and most of the filamentous fungi and bacteria..$^{1,2,5)}$

Studies on the mode of action of aculeacin A or echinocandin B have been published by MizoGuCHI et al. ${ }^{8)}$ and BAGULEY et al. ${ }^{7)}$ The former group of investigators provided biochemical and cytological evidence that aculeacin A selectively inhibits the synthesis of the cell wall, particularly one of its major component alkali-insoluble glucans, in growing cells of Saccharomyces cerevisiae. ${ }^{6)}$ Working with growing cells and protoplasts (or spheroplasts) of S. cerevisiae and Candida albicans, BAGULEY and his coworkers showed that, like aculeacin A, echinocandin B, as well as papulacandin B which is another type of antifungal antibiotic, primarily affects the cell wall synthesis. ${ }^{7)} \quad$ Moreover, our preceding paper demonstrated an unusual antifungal property of aculeacin $\mathrm{A}$; it was most lethal against $C$. albicans at levels of 0.08 to $0.31 \mu \mathrm{g}$ of the drug per $\mathrm{ml}$, but increases in the drug concentration above this range reduced, rather than increased, its fungicidal effect. ${ }^{2}$

Taking into consideration this paradoxical effect of aculeacin A, we carried out in greater details microbiological and biochemical studies on the mechanism of action of this drug, by which sensitive yeast cells are inhibited or killed. Data are presented showing that aculeacin A preferentially inhibits 
formation of the normal cell wall by interfering with the $\beta$-glucan synthetase reaction, with resultant emergence of osmotically fragile cells.

\section{Materials and Methods}

\section{Chemicals}

Samples of purified aculeacin A were generously provided by Dr. K. Mizuno, Toyo Jozo Co., Ltd., Tokyo. $\left[3,4,5-{ }^{3} \mathrm{H}\right]$ Leucine $(120 \mathrm{Ci} / \mathrm{mmole}),\left[8-{ }^{3} \mathrm{H}\right]$ adenine $(25 \mathrm{Ci} / \mathrm{mmole}), \mathrm{D}-\left[\mathrm{U}-{ }^{14} \mathrm{C}\right]$ glucose $(240 \mathrm{mCi} /$ mmole) and uridine diphospho(UDP)-D-[U- $\left.{ }^{14} \mathrm{C}\right]$ glucose ammonium salt $(200 \mathrm{mCi} / \mathrm{mmole})$ were purchased from Radiochemical Centre, Amersham (United Kingdom). All other chemicals were the products of Tokyo Kasei Kogyo Co., Ltd., Tokyo.

\section{Fungal Strains}

Most of our studies were carried out with Candida albicans MTU 12077 which was shown to be highly sensitive to aculeacin A as reported previously. ${ }^{2)}$ This strain was also used, together with Saccharomyces cerevisiae MTU 09018, for preparing cell-free extracts with $\beta$-glucan synthetase activity. In some experiments 24 strains of different species of yeasts belonging to Candida, Torulopsis, Cryptococcus and Sporobolomyces were employed.

Cultivation and Growth Study

Cultures were grown at $37^{\circ} \mathrm{C}$ in PYG broth (Polypeptone $1 \%$, yeast extract $0.5 \%$ and glucose $2 \%$, $\mathrm{pH}$ 5.6). A 24-hour culture was diluted with fresh sterile broth to give approximately $10^{5}$ colony forming units (CFU) per $\mathrm{ml}$, and incubated at $37^{\circ} \mathrm{C}$ on a shaker for 3 hours. Then aliquots $(10 \mathrm{ml})$ of cultures were dispensed into each sterile tube containing a graded concentration of aculeacin A solution prepared in dimethylsulfoxide with a volume of $0.1 \mathrm{ml}$. The incubation was maintained at $37^{\circ} \mathrm{C}$. Samples were withdrawn at intervals to determine optical density at $660 \mathrm{~nm}$ and CFU. CFU was counted by plating dilutions of the samples in broth on PYG agar plates. After 48-hour incubation at $37^{\circ} \mathrm{C}$, the colonies were counted.

\section{Estimation of Osmotic Fragility}

Exponentially growing cells of $C$. albicans were exposed to aculeacin A at concentrations of 0.31 and $20 \mu \mathrm{g} / \mathrm{ml}$ in PYG broth with $0.8 \mathrm{M}$ sorbitol as osmotic stabilizer. Untreated control cultures were also studied. After 3-hour of incubation at $37^{\circ} \mathrm{C}$, samples were removed and diluted in PYG broth and in PYG broth plus stabilizer. CFU were counted on PYG agar containing stabilizer.

\section{Chemical Analysis of Cells}

Exponentially growing cultures of $C$. albicans in PYG broth containing $0.8 \mathrm{M}$ sorbitol were divided into three portions, and aculeacin A at levels of 0.31 and $20 \mu \mathrm{g} / \mathrm{ml}$ was added to the first and the second portions, respectively. The third portion received only a solvent (dimethylsulfoxide) and was used as a control. Immediately after the addition of drug, and after 3 hours of incubation at $37^{\circ} \mathrm{C}, 100-\mathrm{ml} \mathrm{samples}$ were withdrawn and centrifuged. Cells harvested were rinsed with $0.8 \mathrm{M}$ sorbitol and resuspended in water. A portion was fractionated by the method of CHUNG and NICKERSON ${ }^{8)}$ for carbohydrate analysis. The carbohydrate content of each fraction was determined by a modification of $\mathrm{H}_{2} \mathrm{SO}_{4}$-carbazole differential extinction method of MCMUrRough and Rose. ${ }^{9)}$ Another portion of the cell suspensions was fractionated by the method of BROWN and ROSE. ${ }^{10)}$ The extract and residue resulting after extraction with hot $N$-perchloric acid (PCA) were assayed for nucleic acids and protein, respectively. The content of DNA nucleotides in the hot PCA-extract was measured colorimetrically by the diphenylamine method. ${ }^{11)}$ The extinction reading of the hot PCA-extract at $260 \mathrm{~nm}$ was related to the total nucleotide content. The content of RNA nucleotides was calculated by subtracting the estimated value for DNA nucleotides from the total nucleotides. DNA and RNA contents were estimated from the standard curves prepared from calf thymus DNA and yeast RNA, respectively, both of which had been hydrolyzed with PCA. Cell protein was measured by the method of LowRY et al. ${ }^{12)}$ using bovine serum albumin as a standard. 
Incorporation Studies with Growing Cells

Exponentially growing cells of C. albicans were harvested by centrifugation and resuspended in a medium containing $0.4 \%$ glucose and $0.2 \%$ yeast extract supplemented with $0.8 \mathrm{M}$ sorbitol as osmotic stabilizer (GYS medium). An experimental cell suspension was prepared to give approximately $5 \times$ $10^{7} \mathrm{CFU} / \mathrm{ml}$. The reaction mixture contained per $\mathrm{ml}: 0.46 \mathrm{ml}$ GYS medium, $20 \mu \mathrm{l}$ antibiotic solution and $0.5 \mathrm{ml}$ cell suspension. After incubation for 20 minutes at $37^{\circ} \mathrm{C}, 20 \mu \mathrm{l}$ of the labeled precursor were added. The amount of the radioisotope varied according to the isotope studied. The reaction tubes were incubated at $37^{\circ} \mathrm{C}$ with shaking, and appropriate amounts of samples were removed at intervals. Methods used for the incorporation of specific precursors were as follows:

(a) Leucine: Protein synthesis was monitored by determining the incorporation of labeled leucine into hot trichloroacetic acid (TCA)-insoluble materials. The reaction mixture contained $0.04 \mu \mathrm{Ci}(0.01$ $\mu$ mole) of labeled L-leucine per ml. Reaction was terminated by addition of 1 volume of $10 \% \mathrm{TCA}$ $(\mathrm{w} / \mathrm{v})$ and heated at $90^{\circ} \mathrm{C}$ for 15 minutes. The insoluble materials were collected on glass-fiber filters (Whatman, GF/A) and washed. The air dried filters were counted for radioactivity in a toluene-based scintillator fiuid, with an Aloka liquid scintillation counter Model LSC-903.

(b) Adenine: The reaction mixture contained $0.04 \mu \mathrm{Ci}(0.004 \mu \mathrm{mole})$ of labeled adenine per $\mathrm{ml}$. One of samples ( $1 \mathrm{ml}$ each) was added to an equal volume of ice-cold $10 \%$ TCA. The cold TCA-insolubles (RNA plus DNA) were collected on glass fiber filters. Another sample was mixed with one volume of $\mathrm{N} \mathrm{KOH}$, hydrolyzed at $60^{\circ} \mathrm{C}$ for 2 hours, precipitated with $1.8 \mathrm{ml}$ of cold $20 \% \mathrm{TCA}$, and kept overnight at $0^{\circ} \mathrm{C}$. The precipitate (DNA) was collected on glass fiber filters.

(c) Glucose: The reaction contained $0.05 \mu \mathrm{Ci}$ of labeled glucose per $\mathrm{ml}$. Samples in amounts of $2.5 \mathrm{ml}$ were removed and mixed with an equal volume of $10 \%$ TCA to terminate the reaction. Mannan and hot alkali-insoluble glucan fractions were prepared according to the procedure of CHUNG and NICKERSON. ${ }^{8)}$

Incorporation Studies with Cell-free Systems

Cell-free extracts catalyzing the incorporation of glucosyl residues from UDP-[U- $\left.{ }^{14} \mathrm{C}\right] \mathrm{glucose}$ into $\beta$-1,3-glucans were prepared from C. albicans and S. cerevisiae. The methods for preparation of the extracts and the $\beta$-glucan synthetase assays were the same as those described by Lopez-Romero and RUIZ-Herrera. ${ }^{13)}$ Incubation was carried out at $30^{\circ} \mathrm{C}$ for 60 minutes.

\section{Results}

\section{Effect on Growth}

When exponentially growing cells of $C$. albicans in PYG broth were exposed to aculeacin A at concentrations ranging from 0.02 to $20 \mu \mathrm{g} / \mathrm{ml}$ at $37^{\circ} \mathrm{C}$, a considerable loss in viable counts was apparent within one hour (Fig. 1). CFU values for treated cultures decreased progressively with increasing time of incubation. As reported previously2), a paradoxical effect of the antibiotic on viability of $C$. albicans was observed; aculeacin A at a concentration range between 0.08 and $1.25 \mu \mathrm{g} / \mathrm{ml}$ showed the most fungicidal activity, and further increases in the drug concentration progressively reduced its lethal effect (Fig. 1).

As monitored by optical density measurements, aculeacin A at concentrations of 0.08 to $5 \mu \mathrm{g} / \mathrm{ml}$ inhibited the growth of $C$. albicans within one hour, while at concentrations of 0.02 and $20 \mu \mathrm{g} / \mathrm{ml}$ the growth inhibition was not apparent for the first hour after addition of the drug (Fig. 1). Comparable with the results from viability study, the greatest inhibition was obtained with drug concentrations of 0.08 to $1.25 \mu \mathrm{g} / \mathrm{ml}$. At these levels, optical density of cultures started to decrease after 1 to 2 hours, and after 3 to 4 hours the value became considerably lower than the initial value, suggesting lysis of cells. 
Fig. 1. Growth inhibition of Candida albicans by aculeacin A: comparison of viability and cell density.
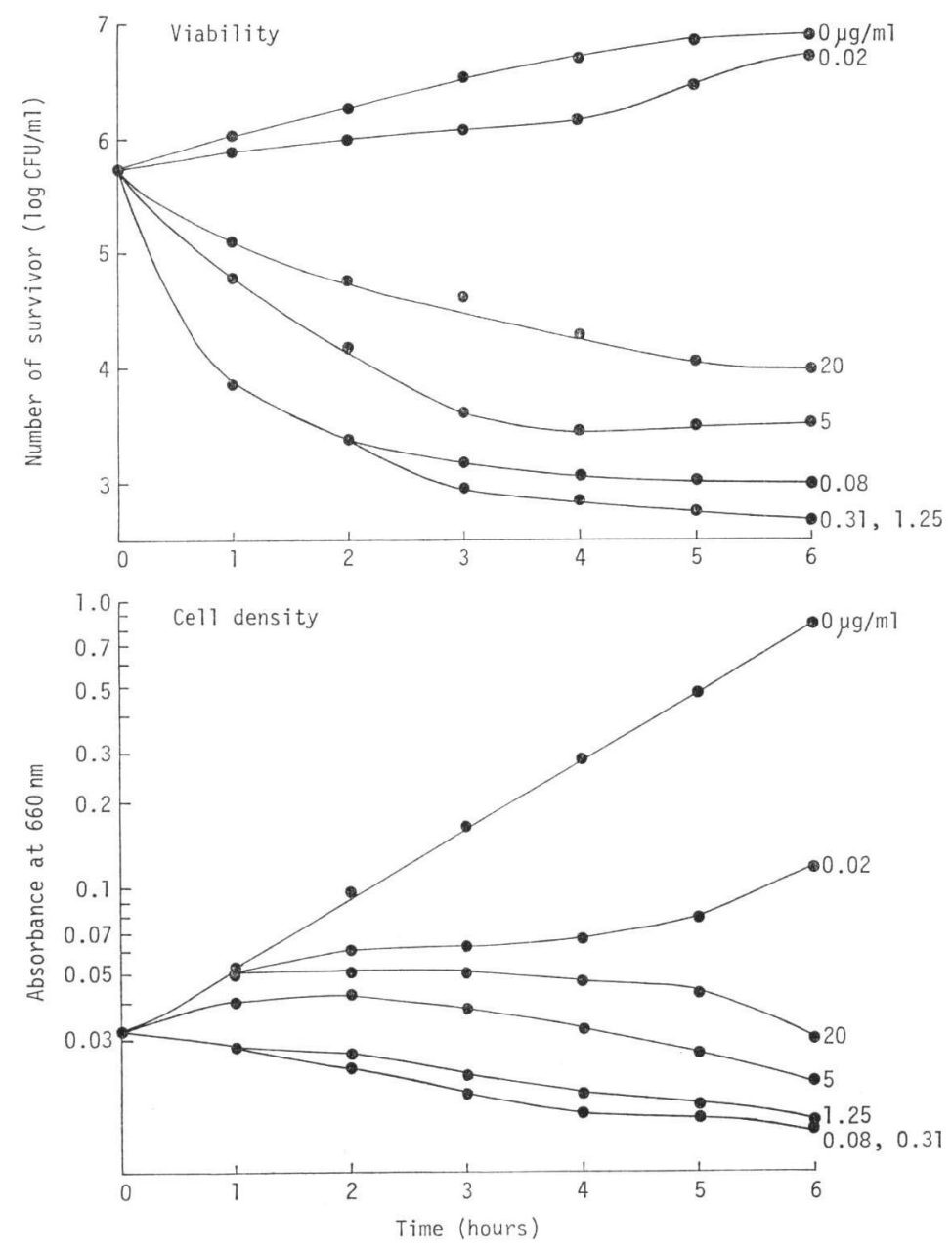

Aculeacin A-insensitivity of Nongrowing Cultures

Previous works of Mizoguchi et al. ${ }^{8)}$ and MiYATA et al. ${ }^{14)}$ with S. cerevisiae and Schizosaccharomyces pombe, respectively, demonstrated that active growth is a prerequisite for a fungicidal action of aculeacin A. To confirm this finding, the effect of the antibiotic on viability of C. albicans was examined in saline and at a suboptimal growth temperature. C. albicans cells were starved by incubation at $37^{\circ} \mathrm{C}$ in saline. After 3 hours, cells were harvested and resuspended in PYG broth or saline. Cell suspensions in PYG broth were divided into three portions, and one was used as control cultures placed at $37^{\circ} \mathrm{C}$. Aculeacin $\mathrm{A}(0.31 \mu \mathrm{g} / \mathrm{ml})$ was added to two similar portions; one of which was incubated at $37^{\circ} \mathrm{C}$ and the other at $0^{\circ} \mathrm{C}$. Cell suspensions in saline also received aculeacin $\mathrm{A}$ and was incubated $37^{\circ} \mathrm{C}$. The number of viable cells in treated and control cultures were determined after $0,1,3$ and 6 hours of incubation. The results showed that nongrowing cells are unaffected by aculeacin A (Table 1).

\section{Aculeacin A-induced Cell Aggregation}

During the course of growth study, it was unexpectedly found that in growing cultures of C. albicans 
Table 1. Effect of aculeacin A on viability of nongrowing cultures of C. albicans.

\begin{tabular}{|c|c|c|c|c|}
\hline \multirow{2}{*}{$\begin{array}{l}\text { Time of exposure } \\
\text { (hours) }\end{array}$} & \multirow{2}{*}{$\begin{array}{l}\text { Control PYG broth } \\
\left(37^{\circ} \mathrm{C}\right)\end{array}$} & \multicolumn{3}{|c|}{ Treated $(0.3 \mu \mathrm{g} / \mathrm{ml}$ of aculeacin A) } \\
\hline & & $\begin{array}{l}\text { PYG broth } \\
\left(37^{\circ} \mathrm{C}\right)\end{array}$ & $\begin{array}{l}\text { PYG broth } \\
\left(0^{\circ} \mathrm{C}\right)\end{array}$ & $\begin{array}{l}\text { Saline } \\
\left(37^{\circ} \mathrm{C}\right)\end{array}$ \\
\hline 0 & $7.2 \times 10^{6}$ & $7.2 \times 10^{6}$ & $7.2 \times 10^{6}$ & $6.6 \times 10^{6}$ \\
\hline 1 & $7.1 \times 10^{6}$ & $4.8 \times 10^{6}$ & $6.5 \times 10^{6}$ & $6.2 \times 10^{6}$ \\
\hline 3 & $1.2 \times 10^{7}$ & $2.5 \times 10^{3}$ & $5.9 \times 10^{6}$ & $2.3 \times 1 C^{6}$ \\
\hline
\end{tabular}

Fig. 2. Aggregation of Candida albicans cells induced by aculeacin A.

Wet-mount specimens were prepared from 30minutes cultures, and photographed with a phasecontrast microscope. Magnification $760 \times$. (A) Control, (B) $0.31 \mu \mathrm{g} / \mathrm{ml}$.
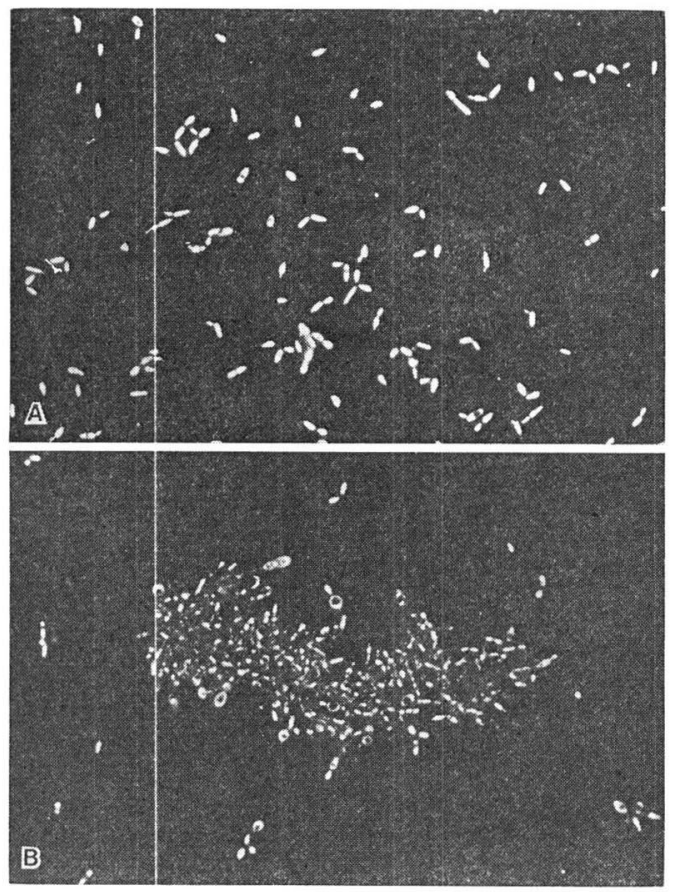

exposed to fungicidal levels of aculeacin A, visible cell aggregates were formed as early as 30 minutes after its addition (Fig. 2). The extent of cell aggregation depended on the drug concentration; it was greatest at concentrations of 0.08 to $1.25 \mu \mathrm{g}$ of the drug per ml. It implies that a marked decrease of viability as monitored by $\mathrm{CFU}$ in aculeacin A-treated cultures of $C$. albicans is partly, at least, due to cell aggregation induced by the drug.
Fig. 3. Morphological changes of Candida albicans cells induced by aculeacin A.

Wet-mount specimens were prepared from 6 hourcultures, and photographed with a phase-contrast microscope. Magnification $1,520 \times$. (A) Control, (B) $0.31 \mu \mathrm{g} / \mathrm{ml}$, (C) $20 \mu \mathrm{g} / \mathrm{ml}$.
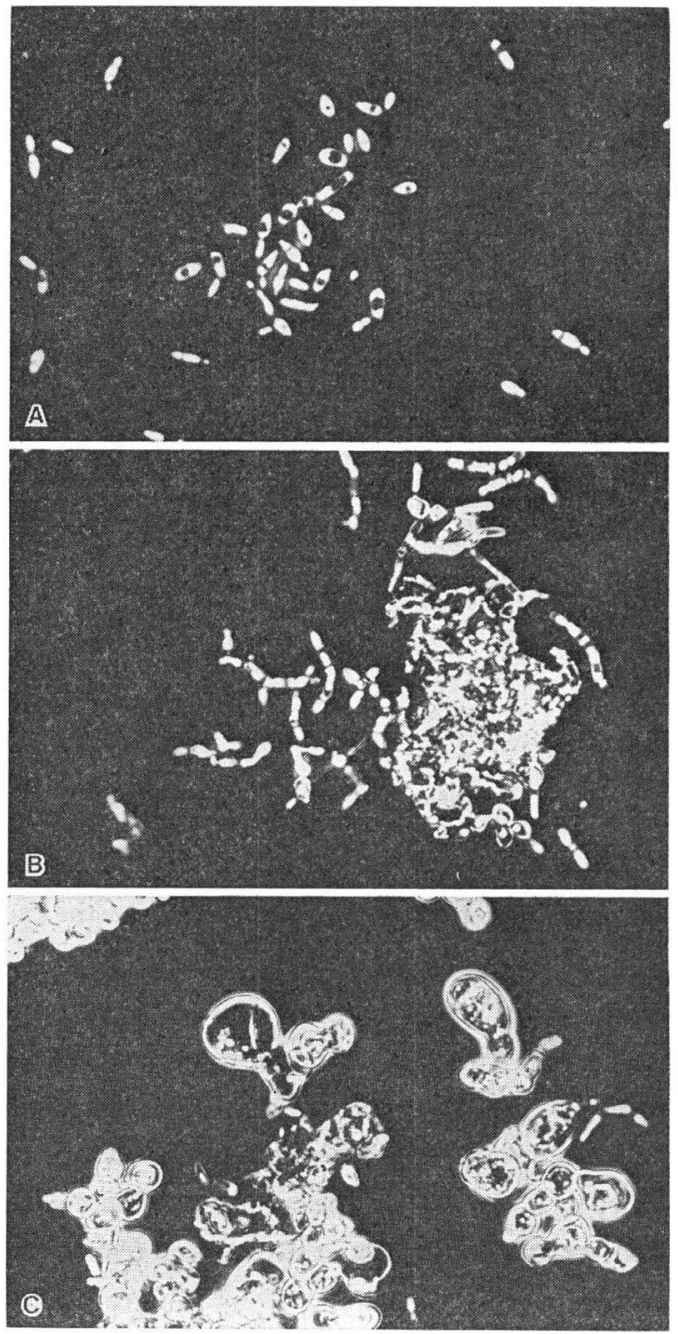
Table 2. Comparison of viable counts of stabilized and osmotically shocked cultures of C. albicans.

\begin{tabular}{|c|c|c|c|c|}
\hline \multirow{3}{*}{ Treatment } & \multicolumn{4}{|c|}{ Exposure } \\
\hline & \multicolumn{2}{|c|}{ 0-hour } & \multicolumn{2}{|c|}{ 3-hour } \\
\hline & Stabilized & Shocked & Stabilized & Shocked \\
\hline None (control) & $8.1 \times 10^{6}$ & $8.3 \times 10^{6}$ & $4.6 \times 10^{7}$ & $4.7 \times 10^{7}$ \\
\hline Aculeacin A, $0.31 \mu \mathrm{g} / \mathrm{ml}$ & $8.3 \times 10^{6}$ & $8.0 \times 10^{6}$ & $7.9 \times 10^{5}$ & $3.5 \times 10^{3}$ \\
\hline Aculeacin A, $20 \mu \mathrm{g} / \mathrm{ml}$ & $8.5 \times 10^{6}$ & $8.1 \times 10^{6}$ & $2.6 \times 10^{6}$ & $7.7 \times 10^{4}$ \\
\hline
\end{tabular}

Cells of C. albicans were exposed to 0.31 and $20 \mu \mathrm{g} / \mathrm{ml}$ of aculeacin A in PYG broth containing $0.8 \mathrm{M}$ sorbitol as osmotic stabilizer. After 3-hour of incubation at $37^{\circ} \mathrm{C}$, cultures were diluted in PYG broth plus stabilizer (stabilized) or in PYG broth without stabilizer (shocked), mixed thoroughly, and finally plated on PYG agar containing stabilizer.

In order to examine whether this phenomenon is correlated with the drug sensitivity of the cells, 15 strains of aculeacin A-sensitive yeasts including C. albicans, C. tropicalis, C. pseudotropicalis, C. krusei, C. guilliermondii and Torulopsis glabrata and 9 strains of insensitive yeasts including Cryptococcus neoformans, Cr. albidus, Cr. laurentii and Sporobolomyces halsaticus were tested for their agglutinability when they were exposed to aculeacin $\mathrm{A}$ in the exponential phase of growth. As a result, formation of cell aggregates was observed with all of the sensitive strains but none of the insensitive ones.

\section{Morphological Changes}

Microscopic examination of growing cultures of $C$. albicans exposed to varying concentrations of aculeacin A for 6 hours or longer periods of incubation time revealed two different types of morphological changes of cells as compared with untreated control cells (Fig. 3A), depending on the drug level; one was disruption of cells, particularly those forming aggregates (Fig. 3B), and the other development of abnormally huge, distorted forms (Fig. 3C). The former type of cytological changes was induced at aculeacin A levels of 0.08 to $0.31 \mu \mathrm{g} / \mathrm{ml}$ and the latter at higher drug levels.

\section{Osmotic Fragility}

As seen in Table 2, plate counts of control cultures grown in the presence of osmotic stabilizer increased six fold during the 3-hour experimental period, whereas a ten fold reduction was observed in cultures exposed to $0.31 \mu \mathrm{g} / \mathrm{ml}$ of aculeacin A. Cultures exposed to $20 \mu \mathrm{g} / \mathrm{ml}$ exhibited three-fold reduction in viability. However, subjection of these cultures to osmotic shock resulted in 2,000-fold and 100 -fold decrease, respectively, in viability. The results suggest that aculeacin A induces formation of osmotically fragile cells. In the osmotically stabilized medium, aculeacin A-induced cell aggregation was markedly inhibited.

\section{Effect on Incorporation of Several Specific Radioactive \\ Precursors into Major Cellular Components}

Effect of aculeacin A on the synthesis of macromolecules and cell wall polysaccharides by growing cells of $C$. albicans in the medium, which was osmotically stabilized to protect cells from lysis, was explored by determination of the counts taken up from the specific radioactive precursors. As given in Fig. 4, aculeacin A caused appreciable inhibition of incorporation of all types of cellular constituents under study, viz. protein, RNA and DNA, as well as mannan and alkali-insoluble glucan. Irrespective of the types of cell constituents synthesized, the greatest inhibition was achieved by aculeacin $\mathrm{A}$ at a concentration of $0.31 \mu \mathrm{g} / \mathrm{ml}$, and the extent of inhibition decreased with increasing drug concentrations 
as was the case for the paradoxical fungicidal effect of this antibiotic. Among different types of cell constituents, synthesis of alkali-insoluble glucan was inhibited to the greatest extent, showing approximately $80 \%$ inhibition at $0.31 \mu \mathrm{g} / \mathrm{ml}$ of the drug, and mannan synthesis inhibition followed in magnitude. The extent of inhibition by aculeacin A of the synthesis of any other macromolecule was lower.

\section{Effect on Cell Composition}

C. albicans cells grown in the osmotically stabilized medium with and without aculeacin A were fractionated and chemically analyzed for several major cellular constituents with special reference to macromolecules and wall polysaccharides. When values of the cellular content of protein, RNA, DNA, mannan and alkali-insoluble glucan for control cultures were compared with comparable values for aculeacin A-treated
Fig. 4. Effect of aculeacin A on incorporation of radioactive precursors into macromolecules in growing cells of Candida albicans.

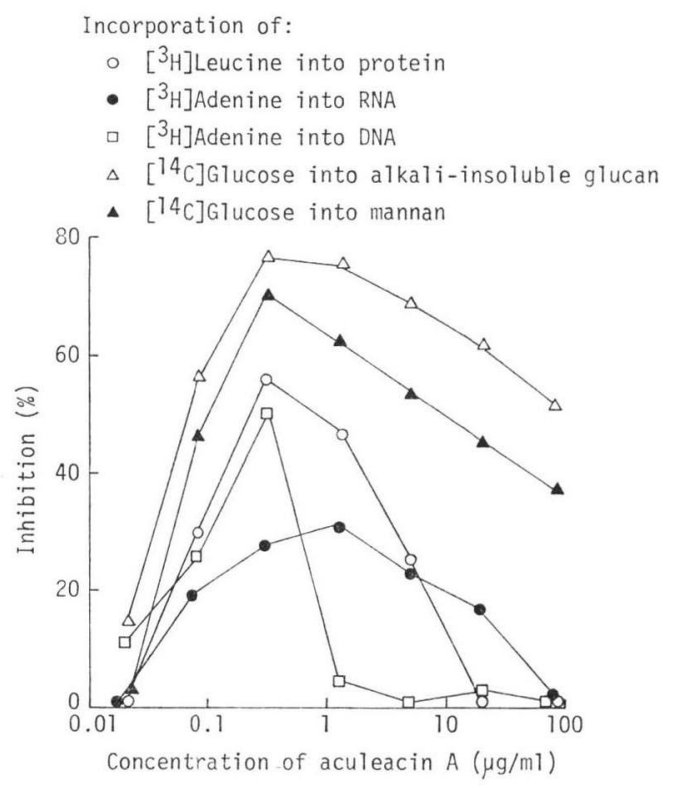
cultures, the most significant difference was found in the content of alkali-insoluble glucan (Table 3). The quantity for treated cultures was approximately four-fold lower than that for control cultures, whereas aculeacin A influenced the content of any other cellular constituent to a lesser extent.

\section{Effect on Cell-free $\beta$-(1,3)Glucan Synthetase Reaction}

In order to examine whether aculeacin A affects an alkali-insoluble glucan synthesizing machinery itself, the effect of the drug on the enzymatic activity of particulate preparations from $S$. cervisiae and $C$. albicans catalyzing the synthesis of $\beta$-glucans from UDP-[U- $\left.{ }^{14} \mathrm{C}\right]$ glucose was studied. Consistent with the results reported by LOPEZ-ROMERO and RUIZ-HERRERA ${ }^{15)}$, glucono- $\delta$-lactone completely inhibited the $\beta$-glucan synthetase reaction in cell-free systems from $S$. cerevisiae (Table 4). The comparable system from $C$. albicans similarly showed high sensitivity to the compound. In both cell-free systems, aculeacin A had a significant inhibitory activity; the maximal inhibition rate reached 60 to $70 \%$ at drug concentra-

Table 3. Chemical composition of control and aculeacin A-treated cultures of C. albicans.

\begin{tabular}{|c|c|c|c|}
\hline \multirow{2}{*}{ Cellular constituents } & \multirow{2}{*}{ Control } & \multicolumn{2}{|c|}{$\begin{array}{l}\text { Treated with aculeacin A at } \\
\text { concentrations of }\end{array}$} \\
\hline & & $0.31 \mu \mathrm{g} / \mathrm{ml}$ & $20 \mu \mathrm{g} / \mathrm{ml}$ \\
\hline Protein $(\mu \mathrm{g} / \mathrm{mg}$ cell $)$ & 145 & $130 \quad(90)^{*}$ & $140(97)^{*}$ \\
\hline RNA $(\mu \mathrm{g} / \mathrm{mg}$ cell $)$ & 37.4 & $29.3(78)$ & $31.4(84)$ \\
\hline DNA $(\mu \mathrm{g} / \mathrm{mg}$ cell $)$ & 1.3 & $0.8(62)$ & $0.7(54)$ \\
\hline Mannan ( $\mu \mathrm{g}$ mannose/mg cell) & 268 & $238 \quad(89)$ & $282 \quad(105)$ \\
\hline $\begin{array}{l}\text { Alkali-insoluble glucan } \\
(\mu \mathrm{g} \text { glucose } / \mathrm{mg} \text { cell })\end{array}$ & 327 & $64.0(20)$ & $75.0(23)$ \\
\hline
\end{tabular}

* Numbers in the bracket are the percentage of control.

Exponentially growing cells of $C$. albicans were incubated with or without aculeacin $\mathrm{A}$ at $37^{\circ} \mathrm{C}$ for 3 hours in PYG broth containing $0.8 \mathrm{M}$ sorbitol as osmotic stabilizer. 
Table 4. Effect of aculeacin A on $\beta$-glucan synthetase reaction by cell-free extracts from $S$. cerevisiae and C. albicans.

\begin{tabular}{l|cc|cc}
\hline \multirow{2}{*}{ Addition } & \multicolumn{2}{|c|}{ S. cerevisiae } & \multicolumn{2}{c}{ C. albicans } \\
\cline { 2 - 4 } & $\begin{array}{c}\beta \text {-Glucan-bound } \\
\text { radioactivity } \\
\text { (c.p.m.) }\end{array}$ & $\%$ Inhibition & $\begin{array}{c}\beta \text {-Glucan-bound } \\
\text { radioactivity } \\
\text { (c.p.m.) }\end{array}$ & $\%$ Inhibition \\
\hline None (control) & 627 & - & 695 & - \\
Aculeacin A, $0.08 \mu \mathrm{g} / \mathrm{ml}$ & 265 & 58 & 268 & 62 \\
Aculeacin A, $0.8 \mu \mathrm{g} / \mathrm{ml}$ & 155 & 75 & 350 & 63 \\
Aculeacin A, $8 \mu \mathrm{g} / \mathrm{ml}$ & 285 & 54 & 252 & 9 \\
Aculeacin A, $80 \mu \mathrm{g} / \mathrm{ml}$ & 366 & 42 & 633 & 100 \\
Glucono- $\delta$-lactone, $10 \mathrm{~mm}$ & 0 & 100 & 0 & 64 \\
\hline
\end{tabular}

After 60 minutes of incubation at $30^{\circ} \mathrm{C}, \beta$-glucan synthesized was measured as described in Materials and Methods.

tions around $0.8 \mu \mathrm{g} / \mathrm{ml}$, whereas the extent of inhibition was considerably lower at the level of $80 \mu \mathrm{g} / \mathrm{ml}$. It appears, therefore, that the paradoxical dose-response pattern of aculeacin A also holds true in these cell-free systems.

\section{Discussion}

Aculeacin A, even at low levels, exerts a fungicidal action towards growing cells of $C$. albicans and some other yeasts, eventually leading to cell lysis. However, nongrowing cultures of these yeasts are refractory to the inhibitory effect of the antibiotic. This suggests that aculeacin A affects some metabolic process(es) essential for cell growth. The same conclusion was reached by Mrzoguchi et al. ${ }^{6)}$ and Miyata et al. ${ }^{14)}$ who worked with other sensitive yeasts, S. cerevisiae and Sch. pombe, respectively. The susceptible cells of $C$. albicans are also shown to behave anomalously in that low concentrations $(0.08 \sim 1.25 \mu \mathrm{g} / \mathrm{ml})$ of aculeacin A are more lethal than higher concentrations. Similar paradoxical dose-response patterns were also observed for the inhibitory effect of this antibiotic on syntheses of various macromolecules and wall polysaccharides in $C$. albicans cells as well as the $\beta$-glucan synthetase reaction catalyzed by cell-free extracts from $C$. albicans and $S$. cerevisiae. Although the details of this paradox remains to be solved, it might be due to the physico-chemical feature of aculeacin A molecules in an aqueous solution. The fact that the molecular structure of this drug consists of a hydrophilic cyclopeptide moiety and a hydrophobic long-chain fatty acid residue moiety leads to the possibility that the drug molecules existing at high levels in an aqueous medium are liable to form micelles which prevent the drug from gaining access to the chemoreceptor and/or the target site.

Provided that the viability is monitored by CFU after the plate counting method, the fungicidal effect of aculeacin A tends to be overestimated. Because appropriate concentrations of aculeacin A rapidly cause susceptible yeast cells to form aggregates of visible size, which, in turn, reduce the efficiency of plate counts of the treated cultures. Aculeacin A-induced cell aggregation takes place only in growing cultures of $C$. albicans and other sensitive yeasts but does not so in nongrowing cultures of these yeasts, implying that there is a causal relationship between this effect of the drug and its inhibition of certain biosynthetic metabolisms.

The fungicidal effect of aculeacin A on growing cultures of $C$. albicans is shown to be effectively reversed in the presence of osmotic stabilizer. It is, therefore, conceivable that an actual loss of viability induced by the drug is largely due to the fact that a large number of treated cells become osmotically fragile and are readily subjected to lysis in a conventional growth medium, like PYG broth, the osmolarity of which is not sufficiently high. Working with Sch. pombe, Mryata et al. ${ }^{14)}$ reported that aculeacin A causes cell lysis which is considerably reduced under high osmolarity and that the site of lysis is on the regions where the wall synthesis occurs. Addition of osmotic stabilizer to the medium is also 
effective in preventing aculeacin A-treated cultures of C. albicans from forming cell aggregation. There are two possible explanations for the aculeacin A-induced cell aggregation: (1) aculeacin A alters the structure of the cell surface through inhibiting synthesis of its component(s) so that it is feasible to adhere with each other; and (2) aculeacin A induces release of some cellular component(s) outside from lyzed cells which functions or function as a cement substance to aggregate the rest of cells in the medium. Our preliminary cytological data suggest the latter more probable.

All the data presented by MiYATA et al. ${ }^{14)}$ and by us in this study show that aculeacin A inhibits formation of the osmotic barrier in susceptible yeasts which is generally known to reside on the cell wall. Highly frequent emergence of extremely huge forms in cultures exposed to relatively high concentrations of aculeacin A might imply that there is a proliferation of cells with defective cell walls from the existing cells surviving the drug treatment. Two main types of polysaccharides, glucans and mannans predominantly occur in the cell wall of yeasts. In Candida and Saccharomyces yeasts, alkali-insoluble glucan, currently believed to be a highly branched $\beta$-1,3-glucan with $\beta-1,6$ linkages at the branching units, has been regarded as the skeletal support of the cell wall. ${ }^{\left.1{ }^{6}\right)}$ Mannan is the more soluble polysaccharide of the cell wall of these yeasts which probably occur as non-fibrillar, amorphous gluco-mannan protein complexes. ${ }^{17)}$ The results of tracer experiments which were carried out with growing cells of $C$. albicans demonstrate that aculeacin $\mathrm{A}$ inhibits synthesis of alkali-insoluble glucan to a greater extent than synthesis of mannan and any species of macromolecules. Consistent with this, chemical analysis of cell composition reveals that the antibiotic induces formation of alkali-insoluble glucan-deficient cells in an osmotically stabilized medium. Mizoguchi et al. ${ }^{6)}$ and BAGuley et al. ${ }^{7)}$ reported preferential inhibition of alkali-insoluble glucan by aculeacin A in growing cells of S. cerevisiae and by papulacandin B and echinocandin B in protoplasts of S. cerevisiae and C.albicans, respectively. Therefore, we are led to the postulation that aculeacin A and probably other related antibiotics primarily and selectively inhibit synthesis of alkali-insoluble glucan in susceptible yeasts, ultimately resulting in development of osmotically fragile cells with defective cell walls. This is partly, at least, supported by data obtained from studies with cell-free extracts showing that aculeacin A substantially inhibits the $\beta$-1,3-glucan synthetase reaction which transfers glycosyl units from UDP-glucose into $\beta$-1,3-linked glucan. ${ }^{13)}$ It is true that some enzymatic process(es) involved in synthesis of $\beta$-1,3-glucan is (are) one of the principal target of aculeacin A action, but its possible effect on other species of wall glucans, such as $\beta$-1,6-glucan and $\alpha$ glucan, cannot be ruled out. Investigations are being continued to study the chemistry of wall glucans, along with the wall architecture, of aculeacin A-treated yeast cells.

Acknowledgement

Technical assistance was provided by A. Ohi, I. Kawamata, N. Kuraishi, M. Sunaga and N. Hirate. Aculeacin A was kindly provided by Toyo Jozo Co., Ltd., Tokyo.

\section{References}

1) Mizuno, K.; A. Yagi, S. Sator, M. Takada, M. Hayashi, K. Asano \& T. Matsuda: Studies on aculeacin. I. Isolation and characterization of aculeacin A. J. Antibiotics 30: $297 \sim 302,1977$

2) Iwata, K.; Y. Yamamoto, H. Yamaguchi \& T. Hiratani: In vitro studies of aculeacin A, a new antifungal antibiotic. J. Antibiotics 35: 203 209, 1982

3) Satoi, S.; A. Yagi, K. Asano, K. Mizuno \& T. Watanabe: Studies on aculeacin. II. Isolation and characterization of aculeacins B, C, D, E, F and G. J. Antibiotics 30: 303 307, 1977

4) Keller-Juslén, C.; M. Kuhn, H. R. Loosli, T. J. Petcher, H. P. Weber \& A. von Wartburg: Struktur des Cyclopeptid-antibiotikums SL 7810 (=Echinocandin B). Tetrahedron Lett. 1976: 4147 4150, 1976

5) Benz, F.; F. Knüsel, J. Nüesch, H. Treichler \& W. Voser: Echinocandin B, ein neuartiges PolipeptidAntibiotikum aus Aspergillus nidulans var. echinulatus: Isolierung und Bausteine. Helv. Chim. Acta 57: $2459 \sim 2477,1974$

6) Mizoguchi, J.; T. Saito, K. Mizuno \& K. Hayano: On the mode of action of a new antifungal antibiotic, aculeacin A: inhibition of cell wall synthesis in Saccharomyces cerevisiae. J. Antibiotics 30: 308 313, 1977

7) Baguley, B. C.; G. Rommele, J. Gruner \& W. Wehrli: Papulacandin B: an inhibitor of glucan synthesis 
in yeast protoplasts. Eur. J. Biochem. 97: 345 351, 1970

8) Chung, C. W. \& W. J. Nickerson: Polysaccharide syntheses in growing yeasts. J. Biol. Chem. 208: 395 406, 1954

9) McMurrough, I. \& A. H. Rose: Effect of growth rate and substrate limitation on the composition and structure of the cell wall of Saccharomyces cerevisiae. Biochem. J. 105: 189 203, 1967

10) Brown, C. M. \& A. H. Rose: Effect of temperature on composition and cell volume of Candida utilis. J. Bacteriol. 97: $261 \sim 272,1969$

11) Schneider, W. C.: Determination of nucleic acids in tissues by pentose analysis. in Methods in Enzymology, Vol. 3, p. 686 693. Eds. S. P. Colowick \& N. O. Kaplan, Academic Press, 1957

12) Lowry, O. H.; N. J. Rosenbrough, A. L. Farr \& R. J. Randall: Protein measurement with the Folinphenol reagent. J. Biol. Chem. 193: 265 275, 1951

13) Lopéz-Romero, E. \& J. Ruiz-Herrera: Biosynthesis of $\beta$-glucans by cell-free extracts from Saccharomyces cerevisiae. Biochim. Biophys. Acta 500: 372 384, 1977

14) Miyata, M.; J. Kitamura \& H. Miyata: Lysis of growing fission yeast cells induced by aculeacin A, a new antifungal antibiotic. Arch. Microbiol. 127: 11 16, 1980

15) Lopéz-Romero, E. \& J. Ruiz-Herrera: Properties of $\beta$-glucan synthetase from Saccharomyces cerevisiae. Antonie van Leewenhoek 44: 329 339, 1978

16) Bartnicki-Garcia, S. \& I. McMurrough: Biochemistry of morphogenesis in yeasts. The Yeasts, Vol. 2 , p. $441 \sim 491$. Eds. A. H. Rose \& J. S. Harrison, Academic Press, 1971

17) Kessler, G. \& W. J. Nickerson: Glucomannan-protein complexes from cell walls of yeasts. J. Biol. Chem. 234: $2281 \sim 2283,1959$ 